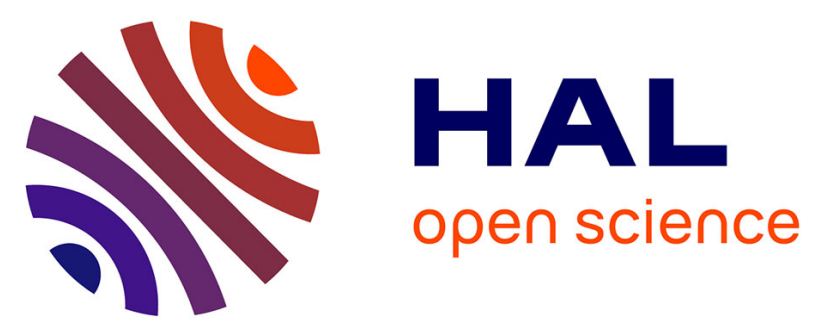

\title{
A comparative review of soil charcoal data: Spatiotemporal patterns of origin and long-term dynamics of Western European nutrient-poor grasslands
}

Vincent Robin, Oliver Nelle, Brigitte Talon, Peter Poschlod, Dominique Schwartz, Marie-Claude Bal, Philippe Allée, Jean-Louis Vernet, Thierry Dutoit

\section{To cite this version:}

Vincent Robin, Oliver Nelle, Brigitte Talon, Peter Poschlod, Dominique Schwartz, et al.. A comparative review of soil charcoal data: Spatiotemporal patterns of origin and long-term dynamics of Western European nutrient-poor grasslands. The Holocene, 2018, 28 (8), pp.1313-1324. 10.1177/0959683618771496 . hal-01788510

\section{HAL Id: hal-01788510 https://hal-amu.archives-ouvertes.fr/hal-01788510}

Submitted on 9 May 2018

HAL is a multi-disciplinary open access archive for the deposit and dissemination of scientific research documents, whether they are published or not. The documents may come from teaching and research institutions in France or abroad, or from public or private research centers.
L'archive ouverte pluridisciplinaire HAL, est destinée au dépôt et à la diffusion de documents scientifiques de niveau recherche, publiés ou non, émanant des établissements d'enseignement et de recherche français ou étrangers, des laboratoires publics ou privés. 


\title{
A comparative review of soil charcoal data: Spatiotemporal patterns of origin and long-term dynamics of Western European nutrient-poor grasslands
}

\author{
Vincent Robin, Oliver Nelle,2 Brigitte Talon,3 Peter Poschlod,4 \\ Dominique Schwartz,5 Marie-Claude Bal,6 Philippe Allée,6 Jean- \\ Louis Vernet7 and Thierry Dutoit3
}

\begin{abstract}
The nutrient-poor grasslands of Western Europe are of major conservation concern because land use changes threaten their high biodiversity. Studies assessing their characteristics show that their past and on-going dynamics are strongly related to human activities. Yet, the initial development patterns of this specific ecosystem remain unclear. Here, we examine findings from previous paleoecological investigations performed at local level on European grassland areas ranging from several hundred square meters to several square kilometers. Comparing data from these locally relevant studies at a regional scale, we investigate these grasslands' spatiotemporal patterns of origin and long-term dynamics. The study is based on taxonomic identification and radiocarbon AMS dating of charcoal pieces from soil/soil sediment archives of nutrient-poor grasslands in Mediterranean and temperate Western Europe (La Crau plain, Mont Lozère, Grands Causses, Vosges Mountains, Franconian Alb, and UpperNormandy region). We address the following questions: (1) What are the key determinants of the establishment of these nutrient-poor grasslands? (2) What temporal synchronicities might there be? and (3) What is the spatial scale of these grasslands' past dynamics? The nutrient-poor grasslands in temperate Western Europe are found to result from the first anthropogenic woodland clearings during the late Neolithic, revealed by fire events in mesophilious mature forests. In contrast, the sites with Mediterranean affinities appear to have developed at earlier plant successional stages (pine forest, matorral), established before the first human impacts in the same period. However, no general pattern of establishment and dynamics of the nutrient-poor grasslands could be identified. Local mechanisms appear to be the key determinants of the dynamics of these ecosystems. Nevertheless, this paleoecological synthesis provides insights into past climate or human impacts on present-day vegetation.
\end{abstract}

\section{Keywords}

fire disturbance, grasslands, human clearance, pedoanthracology, radiocarbon AMS dating, taxonomic

identifications Received 14 November 2017; revised manuscript accepted 19 February 2018

\section{Introduction}

One of the major lessons from paleoecology is that no fixed reference state or baseline exists, and that vegetation is dynamic in time (Birks et al., 2016). Nevertheless, defining targets for environmental management means identifying trajectories, a key issue for conservation, restoration, or sustainability (Bakker et al., 2000; Egan and Howell, 2001). This involves examining the origins of the ecosystem to determine what its trajectory was before a disturbance shifted the ecosystem onto another trajectory (Balaguer et al., 2014).

Identifying the origin of the ecosystem is particularly important in the case of nutrient-poor grasslands. In Europe, these grasslands, also widely known as semi-natural grasslands, are of major conservation importance, presenting high levels of biodiversity (Poschlod and WallisDeVries, 2002) and being threatened by decreased traditional land use (Kahmen and Poschlod, 2004). Human activities have been identified as the key disturbances triggering the presence of nutrient-poor grasslands for at least several millennia (Goepp, 2007; Poschlod and Baumann, 2010; Poschlod et al., 2009). It is thus assumed that without human deforestation and agro-pastoral activities (Bredenkamp et al., 2002), nutrient-poor grasslands would be restricted to locally small, extreme habitats like rock outcrops or extremely steep southfacing slopes with edaphic conditions too dry for tree or shrub growth (Ellenberg, 1996).

1Interdisciplinary Laboratory for Continental Environments, CNRS, University of Lorraine, France

2Baden-Wuerttemberg State Office for Cultural Heritage, Tree-

Ring Laboratory, Germany

3Institut Méditerranéen de Biodiversité et d'Ecologie, CNRS,

IRD, Aix Marseille Univ, Avignon Univ, France

4Institute of Botany, University of Regensburg, Germany

${ }_{5}$ Faculté de géographie et d'aménagement, LIVE, CNRS,

Strasbourg University, France

6GEOLAB, CNRS, Limoges University, France

7 Université de Montpellier II, France

\section{Corresponding author:}

Vincent Robin, Interdisciplinary Laboratory for Continental Environments, CNRS, University of Lorraine, Campus Bridoux, 8 rue du Général Delestraint, 57070 Metz, France. Email: vincent.robin@univ-lorraine.fr 
Over the last decades, the vegetation in most nutrient-poor grasslands (and in other types of grasslands) has been changing due to shrub encroachment. The species typical of the grassland are being excluded, thereby inducing a loss of species richness and diversity (Bonanomi et al., 2013; Habel et al., 2013; Kahmen et al., 2002; Vassilev et al., 2011). Once the human constraint is removed, natural secondary succession takes place (Kahmen and Poschlod, 2004; WallisDeVries et al., 2002). As a consequence of this ongoing habitat change and biodiversity loss, stakeholders have made substantial efforts to conserve and/or restore this type of ecosystem (Dolnik et al., 2009; Schrautzer et al., 2009). Usually, however, not much is known about the primary succession at the spatial scale of present-day grassland distribution, nor about the mechanisms behind the development of such grassland eco-systems. In particular, the respective impacts of recurrent disturbances such as fires, windfalls, and grazing by wild herds remain relatively unexplored (Blakesley and Buckley, 2016; Svenning, 2002; Vera, 1999).

Whether nutrient-poor grasslands are a strictly man-made ecosystem or are of natural origin has been debated for decades (Baumann and Poschlod, 2008; Bush, 1988, 1989, 1993; Thomas, 1989; Wilmans, 1997). This lack of consensus on the origin of nutrientpoor grasslands has so far prevented reference states from being clearly defined (Blakesley and Buckley, 2016). How-ever, recent studies have provided new insights into the local origin and history of various nutrient-poor grasslands in Atlantic, Continental, and Mediterranean Western Europe (Bal et al., 2014; Dutoit et al., 2009; Goepp, 2007; Henry et al., 2010; Poschlod and Baumann, 2010; Schwartz et al., 2005; Vernet, 2006).

Here, we review these studies to investigate whether the ori-gins of the nutrient-poor grasslands show any similarities in chronology and spatial patterns through a large-scale comparison of locally relevant data. Our results are then compared with previous regional pollen data to extend local scale conclusions to the regional scale.

\section{Methods}

Studying the long-term history of nutrient-poor grassland communities (e.g. grasslands established on nutrient-poor soils) is challenging because they are generally restricted to specific small areas (e.g. hilltops). Paleo-indicators significant at a relevant spatial scale need to be collected from areas that rarely offer suitable archives recording and preserving the standard paleo-indicators, such as pollen grains. Analysis of charcoal assemblages from soil/ sediment has been shown to provide suitable paleo-signals, especially relevant at local scale (Nelle et al., 2013; Thinon, 1978). Therefore, the studies hereunder relied on the analysis of macroscopic charcoal pieces accumulated and preserved locally in the soil/sediment (pedoanthracological approach). The charcoal assemblages are composed of macroscopic pieces of $400 \mu \mathrm{m}$ or larger, recorded and preserved locally (Dutoit et al., 2009; Talon, 2010; Touflan et al., 2010). Moreover, the macroscopic charcoal assemblages are extracted either from soil horizons formed in-situ, or from soil sediment eroded and deposited in a catchment area. Thus, the spatial relevance of the charcoal data is related to the size of the catchment area (Robin and Nelle, 2014; Robin et al., 2014). Moreover, the presence of fossil assemblages of charcoal is directly related to fire disturbances that could directly explain past changes in communities.

Following Carcaillet and Thinon (1996), a similar protocol was applied to each site, both to sample the macroscopic charcoal assemblages and to analyze them qualitatively and quantitatively. For each study site considered here, the assemblages of macroscopic charcoal pieces were extracted from natural soil or soil sediment archives. Sampling exposures were dug manually to bedrock and are therefore described in terms of soil horizon and/ or levels of soil sediment accumulation (soil stratigraphy; Robin et al., 2014). Between 5 and $10 \mathrm{~L}$ of material was sampled for each vertical unit described. These vertical sampling units were defined either according to soil horizon or stratigraphy (Goepp, 2007) or by systematic sampling every $10 \mathrm{~cm}$ of depth (Dutoit et al., 2009). The number of exposures per study site varied according to the availability of suitable archive site for sampling and the local sampling strategy to relevantly fit to the surface of the study area (Table 1).

Once sampled, each bag of material was laboratory treated to extract the macroscopic charcoal assemblages. First, the contents of the bag were dried and then weighed. Material larger than $5 \mathrm{~mm}$ was excluded by sieving. Next, the dry material was carefully wet-sieved with a deflocculant (Na4P2O7) through a column of sieves of three mesh sizes: $2 \mathrm{~mm}, 800 \mu \mathrm{m}$, and $400 \mu \mathrm{m}$. The charcoal pieces were then extracted from mineral and organic sections, for each size class of each sample, by hand-sorting under a binocular microscope.

Charcoal pieces were then randomly selected from the extracted charcoal assemblages for taxonomic identification, in balanced proportions from the three size classes of each sample. The charcoal pieces were identified according to wood anatomy criteria, since carbonization of wood fixes the wood anatomy so that it remains visible with only minor deformation and shrinking (Braadbaart and Poole, 2008; Théry-Parisot, 2001). The charcoal pieces were identified under an incident light microscope, mainly at magnifications of $\times 200$ and $\times 500$, and compared with charred wood reference collections and wood anatomy atlases (Jacquiot, 1955; Jacquiot et al., 1973; Schweingruber, 1990).

The macroscopic charcoal signals were actually further quantified per identified taxa, and/or in total amount per vertical unit of sampling, and/or in total amount per profile of sampling, and/ or in charcoal concentration per kilo of sampled material smaller than 5 $\mathrm{mm}$. However, the present comparative study only considered the taxonomically identified charcoal pieces that were directly dated. For each study area, chronological information was gathered from the radiocarbon dating of various quantities of single charcoal pieces, after their formal taxonomic identification. Only these latter data provide insights without reference to the complex and unclear taphonomic processes. These taphonomic processes may significantly influence the recording and preservation of soil charcoal assemblages. In particular, bioturbation causes mixing of assemblages, and fragmentation of the charcoal pieces causes quantitative bias in records (Carcaillet, 2001a, 2001b; Robin et al., 2012). Poorly documented such processes mean that extensive extrapolation is required for taxonomic and chronological interpretation of any unidentified or undated pieces in charcoal assemblages, often with questionable results (Carcaillet and Vernet, 2001; Giesecke, 2016; Robin et al., 2016; Willis et al., 2001).

Since the data on radiocarbon ages and the corresponding taxa identification for single charcoal pieces are less likely to involve extrapolation, the database for this comparative approach uses the C14 measurements of each study site and the corresponding identified taxa. Our database moreover eliminates potential comparative biases due to site-specific variations in sampling strategy at local scale. Nevertheless, of the large quantity of charcoal pieces extracted overall from the different study sites, only a small proportion were identified and dated. Thus, the level of representativeness of the identified and dated taxa at the scale of each investigated site was also taken into account (Table 2).

\section{Study sites}

We considered six Western European nutrient-poor grasslands, ranging widely from nutrient-poor Mediterranean grasslands to nutrient-poor subalpine grasslands in very wet areas, where soil charcoal data were available (Figure 1 and Supplementary material, available online): 

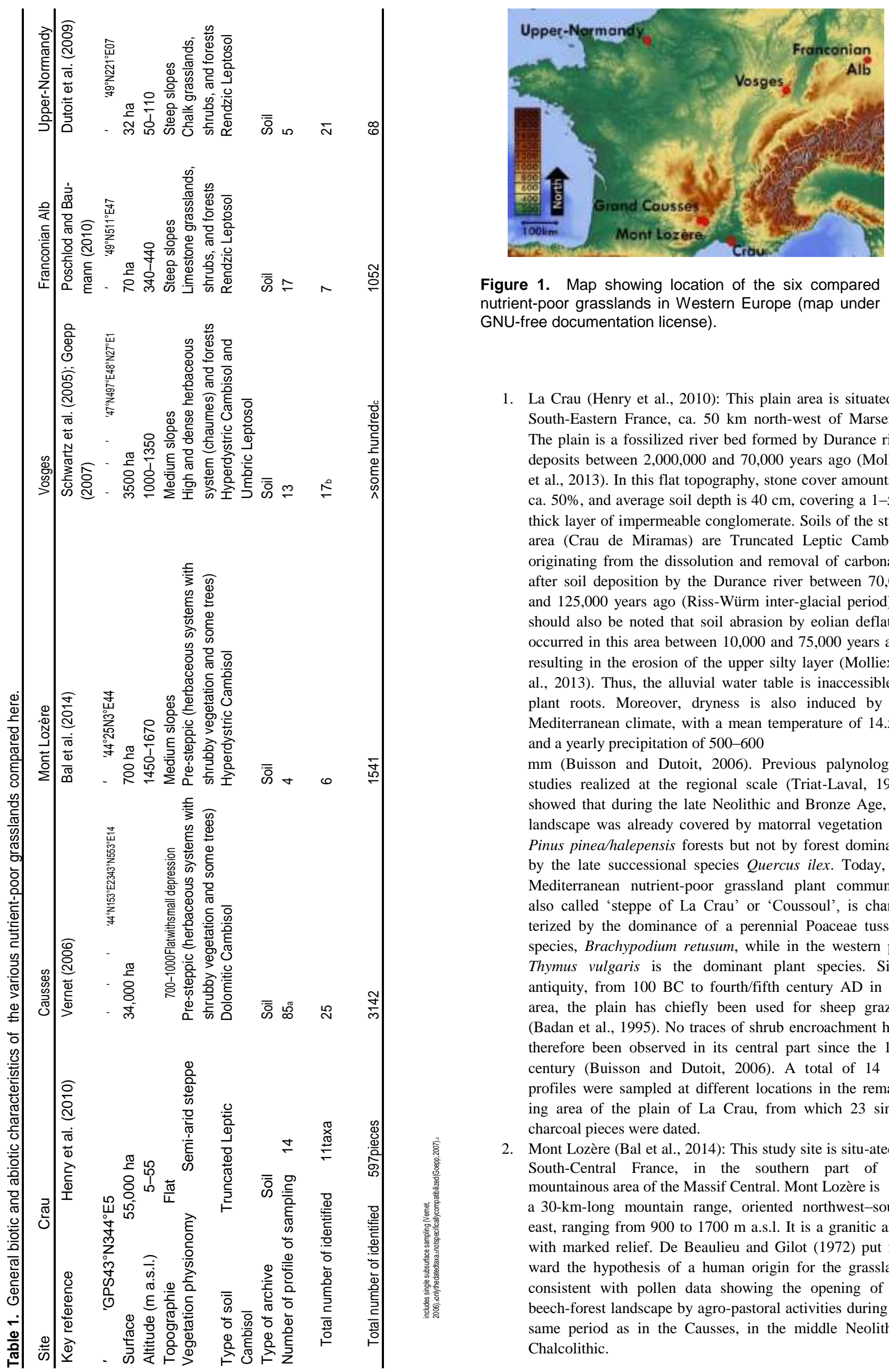

Figure 1. Map showing location of the six compared nutrient-poor grasslands in Western Europe (map under GNU-free documentation license).

1. La Crau (Henry et al., 2010): This plain area is situated in South-Eastern France, ca. 50 km north-west of Marseille. The plain is a fossilized river bed formed by Durance river deposits between 2,000,000 and 70,000 years ago (Molliex et al., 2013). In this flat topography, stone cover amounts to ca. $50 \%$, and average soil depth is $40 \mathrm{~cm}$, covering a $1-5 \mathrm{~m}$ thick layer of impermeable conglomerate. Soils of the study area (Crau de Miramas) are Truncated Leptic Cambisol originating from the dissolution and removal of carbonates after soil deposition by the Durance river between 70,000 and 125,000 years ago (Riss-Würm inter-glacial period). It should also be noted that soil abrasion by eolian deflation occurred in this area between 10,000 and 75,000 years ago, resulting in the erosion of the upper silty layer (Molliex et al., 2013). Thus, the alluvial water table is inaccessible to plant roots. Moreover, dryness is also induced by the Mediterranean climate, with a mean temperature of $14.5^{\circ} \mathrm{C}$ and a yearly precipitation of 500-600

mm (Buisson and Dutoit, 2006). Previous palynological studies realized at the regional scale (Triat-Laval, 1982) showed that during the late Neolithic and Bronze Age, the landscape was already covered by matorral vegetation and Pinus pinea/halepensis forests but not by forest dominated by the late successional species Quercus ilex. Today, the Mediterranean nutrient-poor grassland plant community, also called 'steppe of La Crau' or 'Coussoul', is characterized by the dominance of a perennial Poaceae tussock species, Brachypodium retusum, while in the western part Thymus vulgaris is the dominant plant species. Since antiquity, from $100 \mathrm{BC}$ to fourth/fifth century $\mathrm{AD}$ in this area, the plain has chiefly been used for sheep grazing (Badan et al., 1995). No traces of shrub encroachment have therefore been observed in its central part since the 19th century (Buisson and Dutoit, 2006). A total of 14 soil profiles were sampled at different locations in the remaining area of the plain of $\mathrm{La}$ Crau, from which 23 single charcoal pieces were dated.

2. Mont Lozère (Bal et al., 2014): This study site is situ-ated in South-Central France, in the southern part of the mountainous area of the Massif Central. Mont Lozère is a 30-km-long mountain range, oriented northwest-southeast, ranging from 900 to $1700 \mathrm{~m}$ a.s.l. It is a granitic area, with marked relief. De Beaulieu and Gilot (1972) put forward the hypothesis of a human origin for the grassland, consistent with pollen data showing the opening of the beech-forest landscape by agro-pastoral activities during the same period as in the Causses, in the middle NeolithicChalcolithic. 
Table 2. Radiocarbon ages of the charcoal pieces from the various nutrient-poor grasslands compared here, with information about charcoal assemblages.

\begin{tabular}{|c|c|c|c|c|c|c|}
\hline Area & Laboratory reference & Identified taxa & $\begin{array}{l}\text { Depth layer } \\
\text { (min-max) }\end{array}$ & ${ }_{14} \mathrm{C}$ age yr BP & Calibrated age yr BP & $\begin{array}{l}\text { Representativeness } \\
\text { of the taxa }\end{array}$ \\
\hline \multirow[t]{23}{*}{ Crau } & Poz20310 & Sclerophyllous Quercus & 10-20 & $105 \pm 35$ & $149-11$ & +++ \\
\hline & Poz22605 & Sclerophyllous Quercus & 10-20 & $340 \pm 30$ & $481-311$ & +++ \\
\hline & Poz22609 & Thymus sp. & $15-25$ & $350 \pm 30$ & $492-315$ & ++ \\
\hline & Poz20306 & Sclerophyllous Quercus & $0-10$ & $420 \pm 30$ & $524-435$ & +++ \\
\hline & Poz22599 & Rosaceae & $0-10$ & $600 \pm 30$ & $654-541$ & +++ \\
\hline & Poz22602 & Monocotyledon & $10-20$ & $875 \pm 30$ & $833-726$ & +++ \\
\hline & Poz22598 & Pinus halepensis/pinea & $10-20$ & $1785 \pm 30$ & $1816-1686$ & +++ \\
\hline & Poz20299 & Pinus halepensis/pinea & $20-30$ & $1790 \pm 30$ & $1817-1687$ & +++ \\
\hline & Poz20300 & Cupressus spp. & $20-30$ & $1820 \pm 30$ & $1827-1693$ & ++ \\
\hline & Poz20309 & Pinus halepensis/pinea & $35-45$ & $2025 \pm 30$ & 2061-1895 & +++ \\
\hline & Poz22611 & Pinus halepensis/pinea & $35-45$ & $2045 \pm 30$ & 2114-1926 & +++ \\
\hline & Poz20298 & Quercus sp. & $5-15$ & $2115 \pm 30$ & 2154-1998 & + \\
\hline & Poz22594 & Pinus halepensis/pinea & $0-5$ & $2120 \pm 30$ & 2155-1999 & +++ \\
\hline & Poz20307 & Prunus spp. & 10-20 & $3305 \pm 35$ & $3614-3451$ & +++ \\
\hline & Poz22603 & Prunus spp. & $10-20$ & $3335 \pm 35$ & $3643-3475$ & +++ \\
\hline & Poz22600 & Lavandula sp. & $10-20$ & $3355 \pm 35$ & $3648-3547$ & + \\
\hline & Poz22607 & Prunus spp. & $20-30$ & $3400 \pm 40$ & $3730-3560$ & +++ \\
\hline & Poz22612 & Phillyrea spp. & $10-20$ & $3430 \pm 30$ & $3731-3592$ & ++ \\
\hline & Poz22601 & Prunus spp. & $10-20$ & $3430 \pm 30$ & $3731-3592$ & +++ \\
\hline & Poz22610 & Prunus spp. & $0-10$ & $3435 \pm 35$ & $3779-3606$ & +++ \\
\hline & Poz20301 & Prunus spp. & $5-15$ & $3560 \pm 35$ & 3932-3814 & +++ \\
\hline & Poz22608 & Taxus baccata & $10-20$ & $3745 \pm 35$ & 4163-3984 & + \\
\hline & Poz22597 & Pinus halepensis/pinea & $5-15$ & $3995 \pm 35$ & $4535-4408$ & +++ \\
\hline \multirow[t]{14}{*}{ Mont Lozère } & UGAMS11151 & Fagus sylvatica & $20-30$ & $900 \pm 25$ & $911-741$ & +++ \\
\hline & UGAMS11753 & Fagus sylvatica & $10-20$ & $1140 \pm 25$ & $1146-971$ & +++ \\
\hline & UGAMS11354 & Fagus sylvatica & $30-40$ & $1670 \pm 25$ & $1620-1528$ & +++ \\
\hline & UGAMS9237 & Prunus spp. & $20-30$ & $2180 \pm 25$ & $2308-2121$ & +++ \\
\hline & UGAMS11152 & Fagus sylvatica & $30-40$ & $2170 \pm 25$ & 2308-2112 & +++ \\
\hline & UGAMS14226 & Betula spp. & $50-60$ & $2490 \pm 25$ & $2723-2485$ & + \\
\hline & UGAMS14228 & Fagus sylvatica & $50-60$ & $2730 \pm 25$ & $2870-2768$ & +++ \\
\hline & UGAMS9239 & Prunus spp. & $70-80$ & $3790 \pm 30$ & $4257-4084$ & +++ \\
\hline & UGAMS9240 & Prunus spp. & $70-80$ & $3820 \pm 30$ & $4354-4093$ & +++ \\
\hline & UGAMS11353 & Fagus sylvatica & $50-70$ & $4010 \pm 25$ & $4525-4422$ & +++ \\
\hline & UGAMS11755 & Fagus sylvatica & $50-70$ & $4030 \pm 25$ & $4569-4424$ & +++ \\
\hline & UGAMS11754 & Fagus sylvatica & $40-50$ & $4850 \pm 25$ & $5645-5487$ & +++ \\
\hline & UGAMS9238 & Prunus spp. & $50-60$ & $4870 \pm 30$ & $5655-5583$ & +++ \\
\hline & UGAMS14227 & Prunus spp. & $50-60$ & $5320 \pm 25$ & $6185-6001$ & +++ \\
\hline \multirow[t]{28}{*}{ Grands Causses } & GifA99508 & Fagus sylvatica & $0-20$ & $10 \pm 60$ & $269-0$ & + \\
\hline & GifA9950 & Fagus sylvatica & $0-20$ & $30 \pm 50$ & $268-0$ & + \\
\hline & Lyon1693 & Fagus sylvatica & $10-20$ & $95 \pm 45$ & $272-11$ & + \\
\hline & Erl5597 & Fagus sylvatica & $15-20$ & $102 \pm 47$ & $273-10$ & + \\
\hline & Lyon1696 & Pomoideae & $15-20$ & $115 \pm 40$ & $273-10$ & ++ \\
\hline & Lyon1425 & Pinus type sylvestris & $20-25$ & $150 \pm 30$ & $284-60$ & +++ \\
\hline & AA49141 & Pomoideae & $30-45$ & $158 \pm 32$ & $285-0$ & ++ \\
\hline & Lyon1423 & Fagus sylvatica & $10-20$ & $170 \pm 45$ & $297-59$ & + \\
\hline & GifA99506 & Fagus sylvatica & $0-15$ & $170 \pm 60$ & $302-56$ & + \\
\hline & Lyon1691 & Fagus sylvatica & $10-20$ & $180 \pm 35$ & $301-71$ & + \\
\hline & AA49134 & Buxus sp. & $0-20$ & $201 \pm 33$ & $305-0$ & ++ \\
\hline & Lyon1692 & Fagus sylvatica & $15-20$ & $215 \pm 40$ & $423-82$ & + \\
\hline & Erl5599 & Fagus sylvatica & $0-20$ & $224 \pm 48$ & $430-73$ & + \\
\hline & Lyon1424 & Buxus sp. & $15-20$ & $260 \pm 45$ & $464-146$ & ++ \\
\hline & Lyon 1419 & Fagus sylvatica & $10-20$ & $265 \pm 45$ & $468-148$ & + \\
\hline & Lyon1420 & Fagus sylvatica & $15-25$ & $280 \pm 45$ & $480-151$ & + \\
\hline & Lyon1697 & Deciduous Quercus & $15-20$ & $1045 \pm 40$ & $1059-910$ & + \\
\hline & Lyon1421 & Pinus type sylvestris & $20-30$ & $2570 \pm 50$ & 2776-2489 & +++ \\
\hline & GifA99501 & Pinus type sylvestris & $0-15$ & $2990 \pm 60$ & $3351-2996$ & +++ \\
\hline & GifA99503 & Pinus type sylvestris & $15-30$ & $3020 \pm 60$ & $3369-3031$ & +++ \\
\hline & GifA99504 & Pinus type sylvestris & $15-30$ & $3040 \pm 60$ & $3380-3068$ & +++ \\
\hline & GifA99502 & Pinus type sylvestris & $15-30$ & $3100 \pm 60$ & $3448-3166$ & +++ \\
\hline & Lyon1422 & Fagus sylvatica & $15-30$ & $3200 \pm 50$ & $3561-3342$ & + \\
\hline & GifA99500 & Pinus type sylvestris & $0-15$ & $4180 \pm 60$ & $4849-4566$ & +++ \\
\hline & GifA99505 & Pinus type sylvestris & $0-50$ & $4805 \pm 50$ & $5644-5331$ & +++ \\
\hline & Lyon1694 & Pinus type sylvestris & $0-10$ & $5180 \pm 50$ & $6061-5753$ & +++ \\
\hline & Lyon1695 & Pinus type sylvestris & $0-15$ & $5320 \pm 100$ & $6295-5912$ & +++ \\
\hline & GifA99689 & Pinus type sylvestris & $0-15$ & $5620 \pm 70$ & $6565-6285$ & +++ \\
\hline
\end{tabular}


Table 2. (Continued)

\begin{tabular}{|c|c|c|c|c|c|c|}
\hline Area & Laboratory reference & Identified taxa & $\begin{array}{l}\text { Depth layer } \\
\text { (min-max) }\end{array}$ & ${ }_{14} \mathrm{C}$ age yr BP & Calibrated age yr BP & $\begin{array}{l}\text { Representativeness } \\
\text { of the taxa }\end{array}$ \\
\hline \multirow[t]{40}{*}{ Vosges } & Poz12463 & Abies spp. & $0-5$ & $190 \pm 30$ & $302-32$ & +++ \\
\hline & Poz12467 & Fagus sylvatica & $20-30$ & $250 \pm 30$ & $325-150$ & +++ \\
\hline & Poz6154 & Acerspp. & $20-25$ & $570 \pm 30$ & $646-528$ & +++ \\
\hline & Poz12449 & Fagus sylvatica & $16-21$ & $750 \pm 30$ & $728-664$ & +++ \\
\hline & Poz12464 & Acer spp. & $20-30$ & $765 \pm 30$ & $732-668$ & +++ \\
\hline & Poz12450 & Ericaceae & $16-21$ & $915 \pm 30$ & $920-762$ & ++ \\
\hline & Poz12447 & Abies spp. & $16-21$ & $935 \pm 25$ & $920-793$ & +++ \\
\hline & Poz12453 & Genista spp. & $56-61$ & $1000 \pm 30$ & $967-822$ & + \\
\hline & Poz6147 & Acer spp. & 70-75 & $1280 \pm 30$ & $1288-1176$ & +++ \\
\hline & UtC11538 & Fagus sylvatica & $100-120$ & $1301 \pm 45$ & $1304-1172$ & +++ \\
\hline & UtC11527 & Abies spp. & $20-25$ & $1494 \pm 30$ & $1416-1309$ & +++ \\
\hline & UtC11531 & Abies spp. & $100-120$ & $1930 \pm 60$ & $2000-1717$ & +++ \\
\hline & UtC11529 & Populus spp. & $70-75$ & $1968 \pm 32$ & $1993-1865$ & + \\
\hline & UtC11539 & Juniperus spp. & $20-25$ & $2113 \pm 35$ & $2155-1994$ & ++ \\
\hline & Poz6150 & Fraxinus spp. & $50-55$ & $2125 \pm 35$ & $2297-2001$ & ++ \\
\hline & Poz6145 & Juniperus spp. & $50-55$ & $2135 \pm 30$ & $2300-2004$ & ++ \\
\hline & Poz6144 & Juniperus spp. & $70-75$ & $2210 \pm 30$ & $2320-2148$ & ++ \\
\hline & UtC10893 & Acer spp. & $30-40$ & $2339 \pm 37$ & 2488-2307 & +++ \\
\hline & Poz12451 & Vaccinium sp. & $36-41$ & $2445 \pm 35$ & 2704-2358 & ++ \\
\hline & UtC10895 & Fagus sylvatica & $25-35$ & $2456 \pm 47$ & $2711-2361$ & +++ \\
\hline & UtC10894 & Fagus sylvatica & $50-60$ & $2510 \pm 90$ & $2754-2357$ & +++ \\
\hline & Poz12455 & Calluna sp. & $56-61$ & $2725 \pm 30$ & $2873-2761$ & ++ \\
\hline & Poz6149 & Fagus sylvatica & $70-75$ & $2930 \pm 35$ & 3175-2963 & +++ \\
\hline & UtC11528 & Acer spp. & $50-55$ & $3030 \pm 60$ & $3379-3060$ & +++ \\
\hline & Poz12459 & Abies spp. & $30-35$ & $3060 \pm 35$ & $3361-3177$ & +++ \\
\hline & Poz12465 & Fraxinus spp. & $20-30$ & $3260 \pm 35$ & 3570-3399 & ++ \\
\hline & Poz12469 & Fraxinus spp. & $70-80$ & $3300 \pm 35$ & $3611-3450$ & ++ \\
\hline & Poz12454 & Fagus sylvatica & $56-61$ & $3330 \pm 35$ & $3641-3466$ & +++ \\
\hline & Poz12458 & Acer spp. & $30-35$ & $3400 \pm 35$ & $3723-3565$ & +++ \\
\hline & Poz12457 & Fagus sylvatica & 30-35 & $3460 \pm 30$ & $3830-3641$ & +++ \\
\hline & Poz6151 & Corylus sp. & $20-25$ & $3850 \pm 35$ & $4408-4155$ & + \\
\hline & Poz12452 & Sorbus sp. & $36-41$ & $3885 \pm 35$ & $4420-4230$ & + \\
\hline & Poz12468 & Abies spp. & $70-80$ & $4370 \pm 35$ & 5039-4855 & +++ \\
\hline & Poz6143 & Fagus sylvatica & $100-120$ & $5580 \pm 40$ & $6437-6296$ & +++ \\
\hline & UtC11530 & Tilia spp. & $70-75$ & $6970 \pm 60$ & $7932-7685$ & + \\
\hline & Poz12460 & Salix spp. & $40-45$ & $9260 \pm 60$ & $10,580-10,256$ & + \\
\hline & Poz12461 & Fabaceae & $40-45$ & $9520 \pm 50$ & $11,089-10,660$ & +++ \\
\hline & Poz6208 & Pinus type sylvestris & $50-55$ & $9570 \pm 50$ & $11,125-10,724$ & +++ \\
\hline & Poz6153 & Pinus type sylvestris & $20-25$ & $10,170 \pm 170$ & $12,410-11,260$ & +++ \\
\hline & Poz6146 & Abies spp. & $90-100$ & $18,200 \pm 100$ & $22,348-21,810$ & +++ \\
\hline \multirow[t]{8}{*}{ Franconian Alb } & Erl6167 & Pinus type sylvestris & $0-9$ & $302 \pm 48$ & $487-285$ & +++ \\
\hline & Erl6168 & Pinus type sylvestris & $9-16$ & $399 \pm 122$ & $654-267$ & +++ \\
\hline & Erl6170 & Pinus type sylvestris & $16-26$ & $425 \pm 49$ & $538-425$ & +++ \\
\hline & Erl6169 & Pinus type sylvestris & $5-16$ & $510 \pm 54$ & $570-479$ & +++ \\
\hline & Erl6165 & Pinus type sylvestris & $0-9$ & $573 \pm 49$ & $655-520$ & +++ \\
\hline & Erl6166 & Pinus type sylvestris & $9-20$ & $581 \pm 49$ & $656-525$ & +++ \\
\hline & Erl6163 & Pinus type sylvestris & $12-20$ & $1565 \pm 50$ & $1555-1352$ & +++ \\
\hline & Erl6164 & Pinus type sylvestris & $11-18$ & $1674 \pm 52$ & $1710-1514$ & +++ \\
\hline Upper- & AA59139 & Taxus baccata & $20-40$ & $105 \pm 35$ & $149-11$ & ++ \\
\hline \multirow{13}{*}{ Normandy } & AA59138 & Fagus sylvatica & $20-40$ & $210 \pm 35$ & $223-138$ & ++ \\
\hline & Poz6334 & Fagus sylvatica & $20-40$ & $300 \pm 30$ & $461-347$ & ++ \\
\hline & AA59134 & Deciduous Quercus & $15-35$ & $365 \pm 35$ & $503-315$ & +++ \\
\hline & AA59142 & Deciduous Quercus & $55-80$ & $460 \pm 60$ & $560-425$ & +++ \\
\hline & AA59143 & Deciduous Quercus & $55-80$ & $795 \pm 40$ & $784-671$ & +++ \\
\hline & AA59135 & Deciduous Quercus & $35-55$ & $1190 \pm 35$ & $1185-1048$ & +++ \\
\hline & AA59136 & Fagus sylvatica & $35-55$ & $1990 \pm 40$ & $2043-1864$ & ++ \\
\hline & AA59140 & Taxus baccata & $55-80$ & $3260 \pm 40$ & $3573-3394$ & ++ \\
\hline & AA59141 & Deciduous Quercus & $55-80$ & $3680 \pm 45$ & 4102-3892 & +++ \\
\hline & AA59137 & Taxus baccata & $35-55$ & $3905 \pm 40$ & $4437-4230$ & ++ \\
\hline & AA59133 & Taxus baccata & $15-35$ & $3975 \pm 60$ & $4585-4239$ & ++ \\
\hline & AA59144 & Fagus sylvatica & $0-15$ & $5435 \pm 40$ & $6305-6181$ & ++ \\
\hline & AA59145 & Deciduous Quercus & $35-55$ & $5840 \pm 40$ & $6747-6533$ & +++ \\
\hline
\end{tabular}

+: taxa with low frequency; + +: taxa with medium frequency; + + +: taxa with high frequency. 
Soils are influenced by the leucogranite substratum (silicate rock) and belong to Hyperdystric Cambisol. Mean annual temperature is $6.5^{\circ} \mathrm{C}$ and yearly precipitation is $1500 \mathrm{~mm}$. Old and traditional agricultural systems, where nutrients were translocated through sheep grazing to arable fields, led to this nutrient-poor vegetation (Bal et al., 2014). Vegetation distribution along the slopes of Mont Lozère can be divided as follows: from 400 to $900 \mathrm{~m}$ a.s.l. forests are dominated by Quercus pubescens and Quercus petraea; from 900 to about $1400 \mathrm{~m}$ a.s.l. forests are dominated by Fagus sylvatica, with a few Abies alba; and above $1400 \mathrm{~m}$ a.s.1. lie Nardus stricta grasslands with Vaccinium myrtillus, Calluna vulgaris, Cytisus oro-mediterraneus, and Genista purgans. Sporadically, early successional species such as Pinus sylvestris, Betula pen-dula, and Juniperus nana are encountered. Four soil profiles were sampled in the Nardus stricta grasslands, along an altitudinal transect from $1450 \mathrm{~m}$ to $1670 \mathrm{~m}$ a.s.l. A total of 14 single charcoal pieces was selected and dated.

3. Grands Causses (Causse Méjean \& Causse Larzac; Vernet, 2006): The site of Grands Causses is situated in the same region as Mont Lozère and includes two areas, Causse Méjean and Causse Larzac. Both are located on a Jurassic calcareous-dolomitic plateau from 700 to $1000 \mathrm{~m}$ a.s.l., with an active Karstic system (Corbel, 1954). Soils belonging to Dolomitic Cambisol occurred on Jurassic calcareo-dolomitic substrate. Mean annual temperature is $8-9^{\circ} \mathrm{C}$ and yearly precipitation 1000-1200 mm (Météo France online data). Supramediterranean forest species grow in close proximity to oromediterranean and mediterraneo-montane species (Lecompte and Cohen, 1985). Both areas have distinct zones of forest, dominated by Pinus sylvestris, and grassland traditionally grazed by sheep. Because of the lack of wetlands and peat bogs on the calcareous-dolomitic plateau of the Causses, only one reference was found concerning previous palynological investigations (Van Campo and Aymonin, 1962), simply suggesting the existence of a forest of Pinus sylvestris in the Mesolithic. Moreover, prehistoric traces have already shown that the spread of human settlement in the Causse Méjean began during the Neolithic period, with a peak during the late Neolithic-Chalcolithic. This assumption is based on data from the distribution of archeological remains and is confirmed by the results of Vernet (2006), which support the existence of several phases of fire affecting pine forests in the northern areas of the Causse during the period 4800- 3000 BP cal. yr. Soil and sediment samples in the Grands Causses were taken from natural small topographical depressions, such as dolines, at various locations on the plateau. To ensure the comparability of the data on grass-land history, only samples from open areas were taken into consideration here. A total of 216 samples were collected from 85 subsurface locations and yielded a total of 28 dates (26 from Causse Méjean and 2 from Causse Larzac).

4. Vosges Mountains (Rossberg and Hohneck; Goepp, 2007; Schwartz et al., 2005): The Vosges are a range of low mountains in North-Eastern France, ca. 120 km long, oriented north-south and formed of sandstone and crystalline stones. Their altitude ranges from ca. 300-1424 m a.s.l. Average annual temperature is $8^{\circ} \mathrm{C}$ (Gerardmer station, Météo France), and yearly precipitation is from 1800 to 2000 mm (Météo France on-line data). Janssen and JanssenKettlitz (1972) showed a slight increase of pollen from nonforested herbaceous species in the Bronze Age around $2500 \mathrm{yr} \mathrm{BP}$, but no signs of the existence of former open areas have been detected. Soils from the Vosges sites belong to Hyperdystric Cambisol and Umbric Leptosol originating from the degradation of biotite porphyroid granites under mountainous climate conditions. The grasslands are mainly in the southern half of the massif, where the elevation of the relief leads to what are known as 'chaumes', above ca. 1000 $\mathrm{m}$ a.s.l. The vegetation communities of these grasslands include mainly Nardus stricta, Festuca ovina, and Festuca rubra. They have been grazed by cattle for centuries. Some dwarf shrubs also occur, such as Vaccinium myrtillus and Calluna vulgaris. Sites were investigated on two chaumes: the Rossberg site, with two soil profiles providing 18 radiocarbon dates, and the Hohneck site, with 11 soil profiles providing 22 radio-carbon dates (Schwartz et al., 2014).

5. Franconian Alb (Baumann, 2006; Poschlod and Baumann, 2010): This study site includes several sampling areas in the central and southern Franconian Alb (or Franconian Jura), in South-Eastern Germany. It is a relatively low mountain range, part of the Jura, reaching ca. $600 \mathrm{~m}$ a.s.l. and mainly composed of limestone from the Jurassic period. Poschlod and Baumann (2010) in the same survey compared two different methodological approaches (soil charcoal and pollen analyses) on these sites. Their results show that the peaks of Pinus pollen fully correspond to the periods to which the charcoal found in the calcareous grasslands were dated. Soils of the Rendzic Leptosol type occurred on Jurassic Malm. Mean annual temperature is around $7-8^{\circ} \mathrm{C}$, and yearly precipitation is $600-700 \mathrm{~mm}$ (Baumann, 2006). The main phytosociological association is Gentiano-Koelerietum. A total of 17 profiles from four different sampling areas in formerly grazed grasslands were investigated, and eight radiocarbon dates were obtained.

6. Upper-Normandy (France; Dutoit et al., 2009): The study site is the chalk hillsides of Saint-Adrien situated ca. $100 \mathrm{~km}$ north-west of Paris, in the Lower Seine Valley of UpperNormandy. The Seine River and its tributaries, such as the Bequet River, shaped the geomorphology of cliffs and rocky outcrops on chalk from the Cretaceous period, with hills ranging from 50 to $110 \mathrm{~m}$ a.s.l. Pre-vious palynological studies in the Seine valley showed that forest openings began to occur in the Pre-Boreal Period but that this extensively forested landscape domi-nated by Fagus sylvatica was probably not conducive to large areas of chalk grassland until the late Neolithic (Huault, 1986). The soils of the studied site are Rendzic Leptosol originating from the degradation of the chalk outcrop since the beginning of the post-Glacial period 9,000 years ago. The local topography of steep slopes induces shallow soil, with low wateravailability for vegetation. Thus, vegetation is nutrient-poor dry grassland dominated by Sesleria albicans and Bromus erectus, grazed by sheep, goats, and cattle for centuries (Dutoit et al., 2003). Mean annual temperature is around $10^{\circ} \mathrm{C}$, and yearly precipitation is $800 \mathrm{~mm}$. Five profiles were sampled, one at the base of the hillside and four at the top. The latter four profiles are in an area comparable to the minimum sampling area required to provide a good representation of the floristic composition, richness, and diversity of chalk grassland communities (around $500 \mathrm{~m}^{2}$; Dutoit et al., 2003). In total, 14 single charcoal pieces were dated.

\section{Results}

\section{Soil charcoal synthesis}

A total of 127 single charcoal pieces from the six study sites were radiocarbon dated (Bal et al., 2014; Dutoit et al., 2009; Goepp, 2007; Henry et al., 2010; Poschlod and Baumann, 2010; 


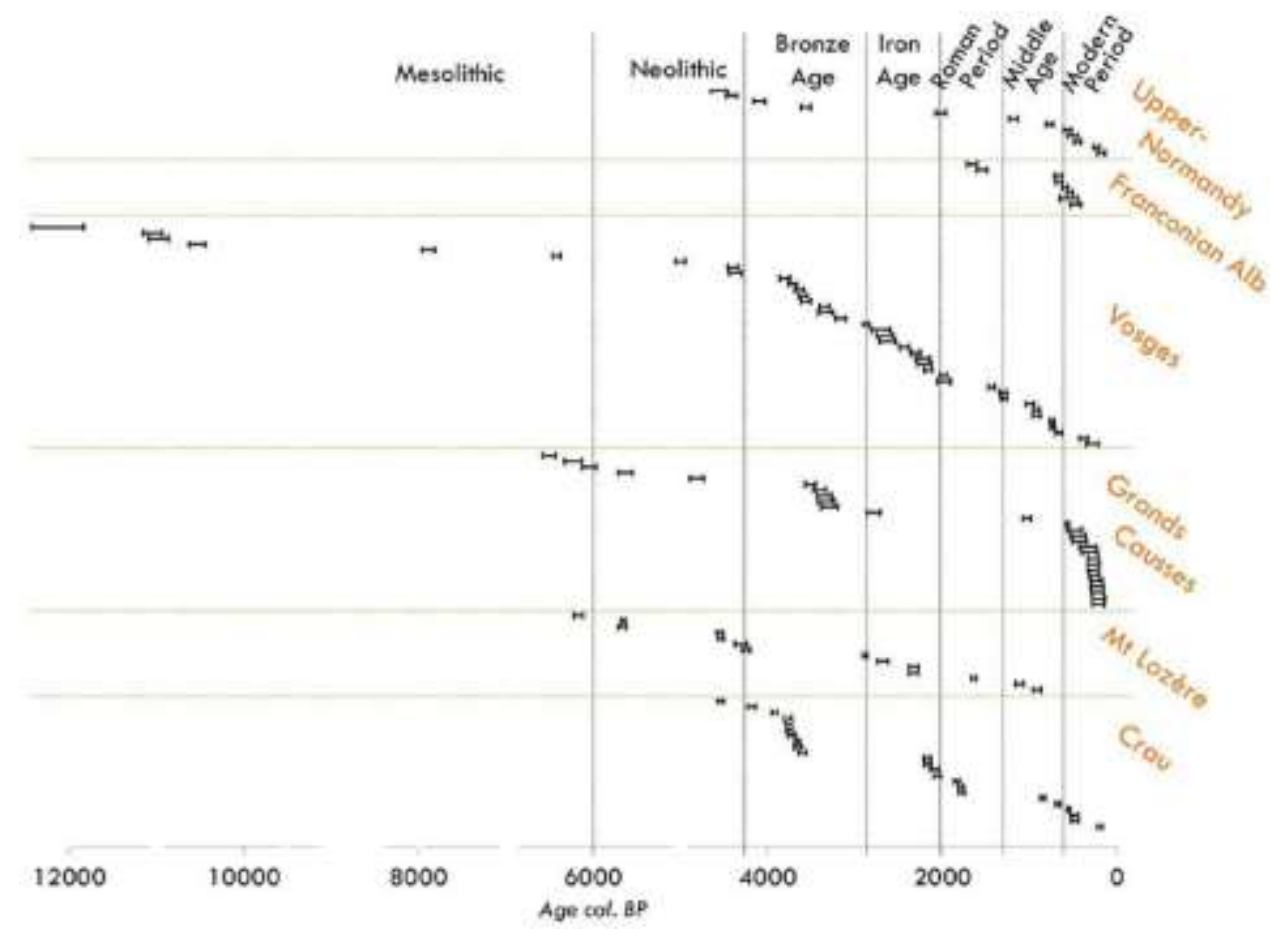

Figure 2. Age distribution of the dated charcoal pieces from the six compared nutrient-poor grasslands in Western Europe, related to the chrono-cultural phases with which the dated charcoal pieces are contemporaneous.

Schwartz et al., 2005; Vernet, 2006; Table 2). When considered together, the ${ }^{14} \mathrm{C}-\mathrm{AMS}$ data compiled show an uneven distribution, both within and between study areas (Figure 2). Obviously, it can be postulated that some soil charcoal pieces could have been lost through charcoal fragmentation and/or soil erosion (Robin and Nelle, 2014). However, the absence of charcoal dates for some periods, for instance, from La Crau area before $5000 \mathrm{cal}$. BP, or before $2000 \mathrm{cal}$. BP in the Franconian Alb, cannot be attributed to the absence of soils, as they were forming or already developed during the early Holocene. While it is true that the soil of La Crau area has been truncated (Molliex et al., 2013), that occurred between 10,000 to 70,000 years ago and not during the period for which dates are lacking. To avoid any over-interpretation, the chronological data are not extrapolated here to the total quantities of charcoal per soil layer; we interpret the chronological data exclusively with reference to the single charcoal pieces dated from each study site.

A clear clustering of dates is only observed during three periods at La Crau: the end of the Neolithic/Bronze Age, the Roman period, and the Medieval period/early Modern period. In Mont Lozère, clustering is less marked: some dates are found loosely grouped in the early Neolithic, others in the late Neo-lithic, then in the Iron Age, with a few isolated dates during the Roman and Medieval periods. The radiocarbon dataset for Grands Causses shows more dates during the Neolithic, the Bronze Age, and the Modern period, with only a few dates dur-ing the Medieval period. The two Vosges areas show differ-ences in the temporal distribution of dates: Hohneck has a few dates occurring together during the early Iron Age, with others during the Medieval period and the Bronze Age, while the Rossberg dates are more concentrated in the Iron Age and the Roman period, with fewer Medieval period dates. Only the Franconian Alb has no dates older than Roman times. Seven dates relate either to the Roman period or to the late Medieval period/early Modern period. The Upper-Normandy dates are more or less grouped in the late Neolithic/Bronze Age and Medieval period/early Modern period. The taxonomic spectrum of the dated charcoal pieces from the various study sites show 30 different taxa in total. The large number of taxa revealed by charcoal analysis in these study areas, compared with single-site or regional studies (e.g. Robin et al., 2013, 2014), is due to their very diverse biogeographic contexts.
Therefore, to ensure comparability between study areas, the dated taxa are grouped here by functional type, according to their lifehistory traits with respect to plant community succession as described in the specialist literature (Denslow, 1980; Rameau et al., $1999,2005,2008)$. Some are early successional taxa, which could indicate a possibly short-lived expansion of shrubs and trees: sclerophyllous Quercus spp., Pinus pinea/halepensis and Pinus type sylvestris (including Pinus nigra, Pinus sylvestris and Pinus uncinata), Cupressus spp., Prunus spp. Phillyrea spp., Acer spp., Genista spp., Populus spp., Juniperus spp., Fraxinus spp., Vaccinium spp., Calluna sp., Corylus sp., Buxus sp., Betula spp., Salix spp., while some characterize strictly open habitats (Lavandula sp., Thymus sp.). A second group consists of taxa tolerant to competition, with Taxus sp., Sorbus spp., and Tilia spp. The last group consists of late successional taxa, with Fagus sp., deciduous Quercus and Abies sp., which are trees that could close the canopy and restrict plants of open vegetation.

The greater number of taxa in the early successional group can be explained by the selection process. Charcoal pieces were usually selected, so as to provide dating as accurate as possible with respect to the fire event. Thus, short-lived species were chosen, and these species are often early successional. Therefore, the dating of the successional groups is not interpreted quantitatively (i.e. by frequency of taxa occurrence) but only qualitatively (i.e. by site-tosite comparison of the chronological occurrence of successional groups). The taxonomic results interpreted according to chronological data are shown in Figure 3.

The plain of La Crau mainly contained early successional species like Pinus pinea/halepensis, Phillyrea sp. (cf. angustifolia), and Prunus sp. at the end of the Neolithic or during the Bronze Age. For these periods, there is no evidence of late successional species. The only dated late successional taxon is from the Roman period. Mont Lozère had early successional taxa before La Crau, notably Prunus sp., as well as late successional taxa such as Fagus sylvatica. Both were already present during the early Neolithic. Then, both groups are dated at various periods during the middle and late Holocene. 


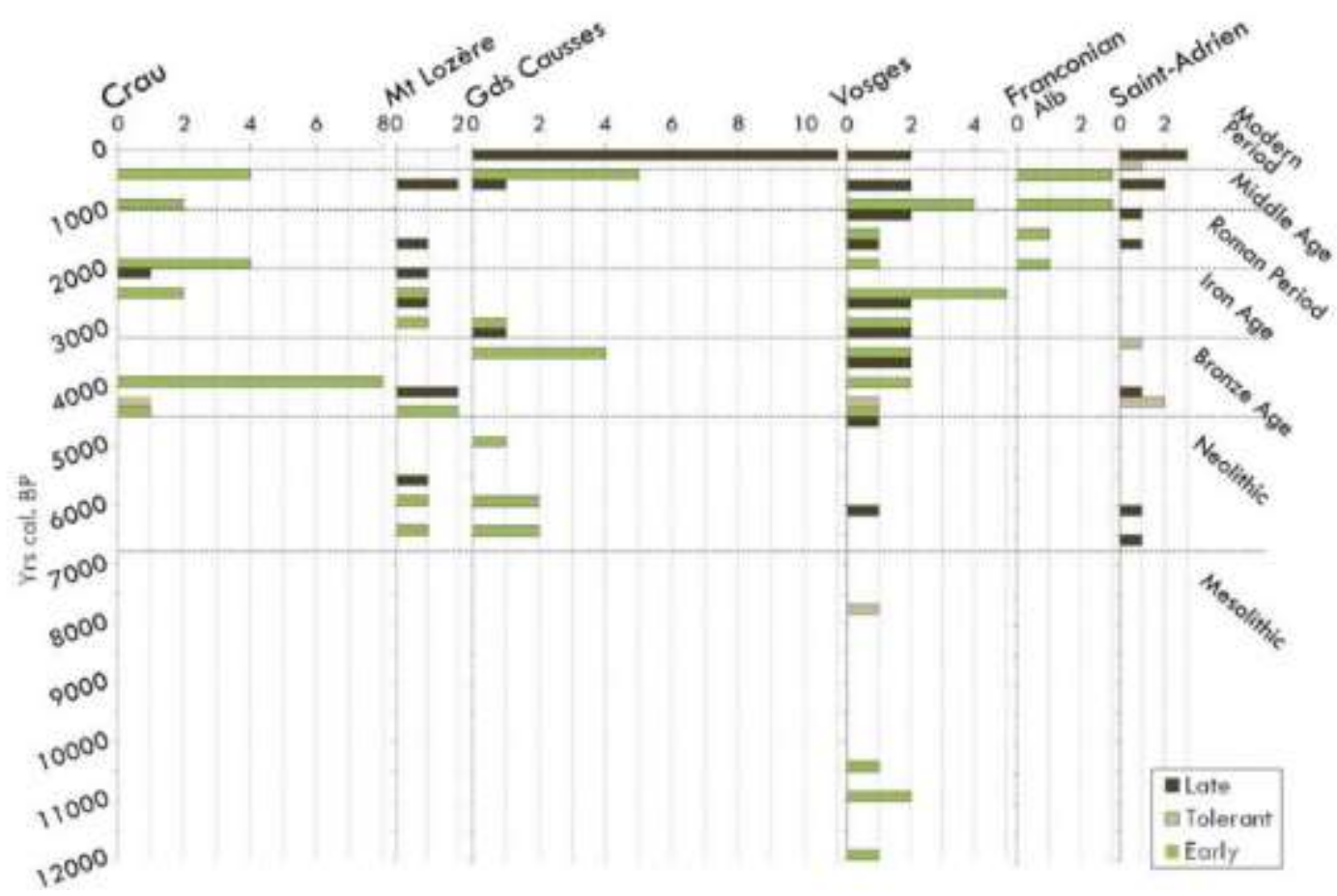

Figure 3. Number of dated charcoal pieces on a time axis per investigated grassland in Western Europe, and per successional group of the identified taxon, related to the chrono-cultural phases with which the dated charcoal pieces are contemporaneous.

On the Grands Causses, several dates for the early successional taxon Pinus type sylvestris are from the late Mesolithic/early Neolithic (as early as the dates for the early successional taxa on Mont Lozère). The dates for late successional taxa are much later, starting with Fagus sylvatica in the late Bronze Age. The subsequent late successional taxa all date from the Modern period. Early successional taxa also show several dates from the Modern period; however, there are more prior occurrences, during the Bronze and Iron Ages. The Vosges contains the oldest dated taxa of the entire dataset, with early successional taxa such as Pinus type sylvestris, and Salix spp. from the Mesolithic. It also contains both a tolerant taxon (Tilia spp.) and a late successional taxon (Fagus sylvatica) dated to the late Mesolithic. Then, from the late Neolithic onward, various taxa from both late and early successional groups occur regularly, up to the Modern period. In the Franconian Alb, the only taxon from the early successional group dated was Pinus type sylvestris, from the Roman period to the Medieval period and the Modern period. However, observations of the charcoal assemblages reveal late successional taxa such as Fagus sylvatica, Abies sp., and deciduous Quercus, along with early successional taxa such as Juniperus and Ligustrum. In Upper-Normandy, no early successional taxa are dated. Thus, although they were most likely present locally at some stages of the forest dynamic, the absence of dating and their weak occurrence within the local soil charcoal assemblages suggest that this vegetation stage did not burn locally. The oldest dating is for late successional taxa from the late Mesolithic; they subsequently occur sporadically in more recent periods, along with tolerant taxa such as Taxus baccata.

\section{Discussion}

The presence of macroscopic charcoal pieces in natural soils indicates the importance of fire as a disturbance in the opening of the ecosystem, as pointed out by the local scale investigations at each site (Bal et al., 2014; Dutoit et al., 2009; Goepp, 2007; Henry et al., 2010; Poschlod and Baumann, 2010; Schwartz et al., 2005; Vernet, 2006). From Prehistoric times until the beginning of the Modern period, our synthesis on soil charcoal data shows that nutrient-poor grasslands existed throughout the study region.

However, caution should be used in interpreting these data, since the charcoal proxy here comes from soil/soil sediment archives. While it was possible to identify the geographical origin of the charcoal signal here by the catchment area of each sampling, taphonomical processes make recording and preservation of such charcoal assemblages inadequate for reliable interpretation. This is an issue particularly regarding transfer of the results to a larger geographical range, such as the regional scale. For instance, there is no relation between the depth of sampling and the measured radiocarbon ages (Carcaillet, 2001a, 2001b). This is why our study sites simply represent a few areas in different landscapes from Northern to Southwestern Europe. Moreover, the spatial distribution of this soil charcoal sampling was designed to capture reliable local information: taxonomic identifications and radio-carbon dating, independently of the archive, to permit their comparison at regional scale. Actually, taxonomic identification and radiocarbon dating yield only partial information, since we have no guarantee that we dated the oldest charcoal pieces of a specific taxa or that we identified all the taxa historically present in the study areas (probably overlooking taxa that did not burn locally for certain chronological periods). Nevertheless, they provide some evidence of the local presence of formally identified taxa for a dated period on the site sampled.

The ${ }^{14} \mathrm{C}$ age distribution points to fire activity occurring locally during the Mesolithic, and from the Neolithic at various sites, but still sporadically. This shows the early role of fire in the dynamics of nutrient-poor grasslands. From the late Neolithic to the Bronze Age, fire activity progressively spread throughout the study sites, consistent with fire history patterns at continental scale in Europe (Carcaillet et al., 2002; Power et al., 2008) and in the Mediterranean (Vannière et al., 2008). However, we were unable to identify clear synchronicities between fires events dated at local scale in different regions. Thus, the fire events in nutrient-poor grasslands at local scale are highly heterogeneous, probably due to the existence of local semi-open mosaics of fuel and to specific local scale fire regime drivers, like local vegetation dynamics, human activities, 
and potential effects from recurrent grazing by wild herds in the Mesolithic (Robin et al., 2012). How-ever, during this period, the impacts of wild herds on the degree of vegetation opening (in space and time) could not be reliably assessed from natural bone archeological traces (Svenning, 2002). Thus, the key impact of wild herds on vegetation openness and maintenance of nutrient-poor grasslands during the Mesolithic periods in Europe is still purely a hypothesis (Vera, 1999), as the precise dynamics of wild herds have not yet been determined.

However, identifying the ignition sources of the dated char-coal is challenging. The soil charcoal database does not enable us to assess directly whether fire activity is related to human activities or to climate forcing, since the fire responsible for the presence of charcoal assemblages can be either natural or human-made. In addition, the charcoal recorded might result from the domestic use of wood for cooking, even out of archeological archives or be related to clearly identified human occupation sites such as La Crau plain (Henry et al., 2010). However, the taxonomic identification and radiocarbon dating of these charcoal pieces possibly from 'hearths' still provide direct evidence of the local presence of some taxa for some periods. From the local charcoal assemblages, therefore, two groups of sites can be distinguished: one at northernmost latitudes (i.e. Upper-Normandy, Vosges, Franconian Alb), and one with Mediterranean affinities (i.e. Grands Causses, Mont Lozère, La Crau).

For the first group, the impact of man-made fire is plausible considering that the burnt vegetation is identified as originating from low flammable forest systems since at least the Neolithic for the Vosges and Normandy sites (i.e. presence of Fagus sylvatica, Abies sp., and/or deciduous Quercus; Dutoit et al., 2009; Goepp, 2007; Poschlod and Baumann, 2010; Schwartz et al., 2005; Figure 3). The role played by human disturbance in the emergence of grassland ecosystems has already been pointed out by paleo-investigations of other European grassland sites (e.g. Bush, 1988, 1989). These studies feed into the debate on whether human disturbance should be seen as causing the development of grassland or as maintaining existing grassland inherited from cold periods (Bush, 1993; Thomas, 1989). The soil charcoal dataset for the sites considered here supports the hypothesis that nutrient-poor grasslands in Western Europe are the result of woodland opening since the Neolithic, which became even more marked during the Bronze Age, Roman Empire, and Medieval Age. This is consistent with the Holocene vegetation history of Western Europe: reestablishment of closed canopy forest during the early/middle Holocene (ca. 8-4 ka yr BP), followed by progressive afforestation related to human activities and use of natural resources (e.g. Berglund et al., 1996; Kalis et al., 2003; Robin et al., 2014). This is especially marked for the late Holocene (ca. the last $4 \mathrm{ka}$ yr BP), which saw the onset of human use of fire as a tool to open wooded areas (Marlon et al., 2008), related to the development of cultural landscapes (Gaillard et al., 2007).

For the second group (Grands Causses, La Crau), with the sites at lower latitudes, fires may have occurred naturally due to the presence of highly flammable vegetation (e.g. pine woodland; Bal et al., 2014; Henry et al., 2010; Vernet, 2006; Figure 3). The importance of wildfire related to summer drought as a key disturbance during the Holocene in the Mediterranean region has already been shown (Vannière et al., 2011), supporting climate determinism (Combourieu-Nebout et al., 2013; Jalut et al., 2009; Pons and Quezel, 1998; Thiebault, 1997). In La Crau, the charcoal assemblages show a degradation of pre-existing matorral vegetation and pine forests by fire and grazing during the Neolithic, before any advanced forest succession established locally (Bazile-Robert, 1987; Henry et al., 2010). In the Grands Causses sites, the same pattern emerges even earlier, with fire occurrences in pioneer forests from the beginning of the Mesolithic and the Neolithic (Bal et al., 2014; Vernet, 2006). This early successional vegetation type remained dominant during the Neolithic, probably because the Mediterranean climate and soil erosion slowed primary plant successions (Carrión et al., 2003; Grove and Rack-ham, 2003). Human activities intensified the effect of climate constraint, keeping open ecosystems dominated by herbaceous plant communities, notably through grazing (Henry et al., 2010; Vernet, 2006).

A relatively similar phenomenon has been observed in Central Europe, where natural grasslands occurred even before the start of agricultural activities in the early Neolithic (5500 BC). However, their area was estimated to be relatively small and grassland patches were probably rather fragmented in a dominantly forested landscape matrix. Thus, large-scale enlargement of grasslands is not expected to have occurred before the Iron Age (Hájková et al., 2011; Hejcman et al., 2012; Kuneš et al., 2015; Pokorny et al., 2015).

Finally, on Mont Lozère, the finding of some Fagus sylvatica dates from the Neolithic points to the presence of mature stands before the establishment of grassland. However, for the same period and from the same charcoal assemblages, pioneer forest vegetation was also found (i.e. Betula spp., Salix spp., Corylus avellana; Bal et al., 2014). Thus, it can be postulated that the Fagus dates do not result from dense closed forests. The high altitude of the Mont Lozère grasslands sampled, with their wet mountain climate, explain the differences from La Crau and even from Grands Causses, where climate conditions are much drier. However, for those three study sites with Mediterranean affinities, it is clearly shown that the first fire events occurred in non-mature forest stages, as revealed by charcoal assemblages. This is an important distinction, marking them out at large scale from the study sites at northernmost latitudes, where the first fire occur-rences were in late successional forest stages.

Concerning the last few hundred years, the absence of charcoal from this period in La Crau, Mont Lozère, and the Franconian Alb may indicate a continuous openness of these grasslands. This may have led to higher floristic diversity for sites not plowed during the Modern period (Dutoit et al., 2003; Forey and Dutoit, 2012; Gibson and Brown, 1992; Karlík and Poschlod, 2009; Römermann et al., 2005). Grassland diversity has already been linked to late Iron Age human population density (Pärtel et al., 2007). Conversely, the abundance of young charcoal from Fagus should indicate that the other grasslands are younger and would quickly disappear if human land use stopped. These grasslands would certainly differ floristically. However, since our sites are situated in different biogeographic areas, testing this hypothesis would require discriminating climatic factors from those linked to history and landscape organization at the regional and local scale across Europe (Cousins and Eriksson, 2002).

\section{Conclusion}

Comparing the locally relevant chronological and taxonomic data for the six study areas revealed no clear pattern of nutrient-poor grassland development and dynamics between areas in contrasting parts of Europe. Local-scale mechanisms appear to be the dominant drivers of these ecosystems. It can be concluded that the origin and history of European nutrient-poor grasslands are related to a combination of climatic constraint and/or human influence impacting vegetation dynamics at local or at least 'infra-regional' scale. Nevertheless, we observed a clear distinction between the sites under Mediterranean influence (i.e. Grands Causses, Mont Lozère, and $\mathrm{La} \mathrm{Crau}$ ), where matorral and pioneer forest stages were already established when the first human impacts occurred during the Neolithic, and the sites at central Europe latitudes (i.e. UpperNormandy, Vosges, and Franconian Alb), where the grassland appears to result more from anthropogenic woodland clearing from the Neolithic onwards. Moreover, comparisons between local 
pedoanthracological data and previous regional pollen data clearly show how the results can be additional for a better understanding of the spatial areas really affected by vegetation changes. Here, charcoal-based data suggest a Prehistoric origin for nutrient-poor grasslands (from the Neolithic to the Bronze age) but their extension in space appears to have occurred no earlier than the Middle-Ages according to most of the regional pollen analyses previously realized in our study regions.

\section{Acknowledgements}

We thank Marjorie Sweetko for English language revision.

\section{Funding}

This publication was made possible by the financial support for a research stay to Oliver Nelle and Vincent Robin provided by the University of Avignon.

\section{ORCID iD}

Peter Poschlod https://orcid.org/0000-0003-4473-7656

\section{References}

Badan O, Brun J-P and Congès G (1995) Les bergeries romaines de la crau d'Arles. Les origines de la transhumance en Provence. Gallia 52: 263-310.

Bakker JP, Grootjans AP, Hermy M et al. (2000) How to define targets for ecological restoration? Introduction. Applied Vegetation Science 3: 1-72.

Bal MC, Allée P and Liard M (2014) Charcoal from soil: The origin of Nardus stricta grassland and the history of a mountain cultural landscape (Mont Lozère, France) since the Neolithic period. Quaternary International 366: 3-14.

Balaguer L, Escudero A, Martín-Duque JF et al. (2014) The historical reference in restoration ecology: Redefining a cornerstone concept. Biological Conservation 176: 12-20.

Baumann A (2006) On the vegetation history of calcareous grasslands in the Franconian Jura (Germany) since the Bronze age. $\mathrm{PhD}$ Thesis, University of Regensburg.

Baumann A and Poschlod P (2008) Did calcareous grasslands exist in prehistoric times? An archaeobotanical research on the surroundings of the prehistoric settlement above Kall-münz (Bavaria, Germany). British Archaeological Reports International Series 1807: 25-37.

Bazile-Robert E (1987) Végétations pré-néolithiques d'après l'anthracoanalyse de sites préhistoriques du sud de la France. In: Guilaine J, Courtin J, Roudil JL et al. (eds) Premières communautés paysannes en Méditerranée occidentale. Paris: CNRS Edition, pp. 81-85.

Berglund BE, Birks HJB, Ralska-Jasiewiczowa M et al. (1996) Palaeoecological Events during the Last 15,000 Years: Regional Synthesis of Palaeoecological Studies of Lakes and Mires in Europe. Hoboken, NJ: John Wiley and Sons.

Birks HJB, Felde VA, Bjune AE et al. (2016) Does pollenassemblage richness reflect floristic richness? A review of recent developments and future challenges. Review of Palaeobotany and Palynology 228: 1-25.

Blakesley D and Buckley P (2016) Grassland Restoration and Management. Exeter: Pelagic Publishing.

Bonanomi G, Incerti G and Allegrezza M (2013) Assessing the impact of land abandonment, nitrogen enrichment and fairy-ring fungi on plant diversity of Mediterranean grasslands. Biodiversity and Conservation 22: 2285-2304.

Braadbaart F and Poole I (2008) Morphological, chemical and physical changes during charcoalification of wood and its relevance to archaeological contexts. Journal of Archaeological Science 35: 2434-2445.
Bredenkamp GJ, Spada F and Kazmierczak E (2002) On the ori-gin of northern and southern hemisphere grasslands. Plant Ecology 163: 209-229.

Buisson E and Dutoit T (2006) Creation of the natural reserve of La Crau: Implications for the creation and management of protected areas. Journal of Environmental Management 80: 318-326.

Bush MB (1988) Early Mesolithic disturbance: A force on the landscape. Journal of Archaeological Science 15: 459-462.

Bush MB (1989) On the antiquity of British chalk grasslands: A response to Thomas. Journal of Archaeological Science 16: $555-560$.

Bush MB (1993) An 11400 years paleoecological history of a British chalk grassland. Journal of Vegetation Science 4: 47-66.

Carcaillet C (2001a) Are Holocene wood-charcoal fragments stratified in alpine and subalpine soils? Evidence from the Alps based on AMS 14C dates. The Holocene 11: 231-242.

Carcaillet C (2001b) Soil particles reworking evidences by AMS 14C dating of charcoal. Comptes Rendus de l'Académie des Sciences - Series IIA - Earth and Planetary Science 332: 2128.

Carcaillet C and Thinon M (1996) Pedoanthracological contribution to the study of the evolution of the upper treeline in the Maurienne Valley (North French Alps): Methodology and preliminary data. Review of Palaeobotany and Palynology 91: 399-416.

Carcaillet C and Vernet J-L (2001) Comments on 'The Full-Gla-cial Forests of Central and Southeastern Europe' by Willis et al. Quaternary Research 55: 385-387.

Carcaillet C, Almquist H, Asnong H et al (2002) Holocene bio-mass burning and global dynamics of the carbon cycle. Che-mosphere 49: 845-863.

Carrión JS, Sánchez-Gómez P, Mota JF et al (2003) Holocene vegetation dynamics, fire and grazing in the Sierra de Gádor, southern Spain. The Holocene 13: 839-849.

Combourieu-Nebout N, Peyron O, Bout-Roumazeilles V et al. (2013) Holocene vegetation and climate changes in the cen-tral Mediterranean inferred from a high-resolution marine pollen record (Adriatic Sea). Climate of the past 9: 2023- 2042.

Corbel J (1954) Les phénomènes karstiques dans les Grands Causses. Revue de Géographie De Lyon 29: 287-315.

Cousins SAO and Eriksson O (2002) The influence of manage-ment history and habitat on plant species richness in a rural hemiboreal landscape, Sweden. Landscape Ecology 17: 517529.

De Beaulieu J-L and Gilot E (1972) Végétations holocènes du mont Lozère: Analyses polliniques et datages. Comptes Ren-dues Académie des Sciences 274: 1641-1644.

Denslow JS (1980) Patterns of plant species diversity during succession under different disturbance regimes. Oecologia 46: $18-21$.

Dolnik C, Dengler J, Jandt U et al. (2009) Dry grasslands in a changing environment - Special feature with contributions from the 5th dry grassland meeting 2008 in Kiel. Tuexenia 29: 331337.

Dutoit T, Buisson E, Roche P et al. (2003) Land use history and botanical changes in the calcareous hillsides of Upper-Normandy (North-Western France): New implications for their conservation management. Biological Conservation 115: 1-19.

Dutoit T, Thinon M, Talon B et al. (2009) Sampling soil wood charcoals at a high spatial resolution: A new methodology to investigate the origin of grassland plant communities. Journal of Vegetation Science 20: 349-358.

Egan D and Howell EA (2001) The Historical Ecology Hand-book: A Restorationist's Guide to Reference Ecosystems. Washington, DC: Island Press. 
Ellenberg H (1996) Vegetation Mitteleuropas Mit Den Alpen. 5th Edition. Stuttgart: Eugen Ulmer.

Forey E and Dutoit T (2012) Vegetation, soils and seed banks of limestone grasslands are still impacted by former cultivation one century after abandonment. Community Ecology 13: 194-202.

Gaillard MJ, Dutoit T, Hjelle K et al. (2007) European cultural landscape - Insights into origins and development. In: Krzywinski K, O'Connell $\mathrm{M}$ and Küster $\mathrm{H}$ (eds) Cultural Landscapes in Europe. Delmenhorst: Aschenbeck and Holstein Publishers, pp. 35-44.

Gibson CWD and Brown VK (1992) Grazing and vegetation change: Deflected or modified succession? Journal of Applied Ecology 29: 120-131.

Giesecke T (2016) Did thermophilous trees spread into central Europe during the Late Glacial? New Phytologist 212: 15-18.

Goepp S (2007) Origine, histoire et dynamique des Hautes-Chaumes du massif vosgien - Déterminismes environnemen-taux et actions de l'Homme. PhD Thesis, University of Strasbourg.

Grove AT and Rackham O (2003) The Nature of Mediterranean Europe: An Ecological History. New Haven, CT: Yale University Press.

Habel JC, Dengler J, Janišová M et al. (2013) European grassland ecosystems: Threatened hotspots of biodiversity. Biodiversity and Conservation 22: 2131-2138.

Hájková P, Rolecek J, Hájek M et al. (2011) Prehistoric origin of the extremely species-rich semi-dry grasslands in the Bílé Karpaty Mts (Czech Republic and Slovakia). Preslia 83: 185-204.

Hejcman M, Hejcmanová P, Pavlů V et al. (2012) Origin, history, management and plant species composition of grasslands in Central Europe - A review. Grassland Science in Europe 17: 554-567.

Henry F, Talon B and Dutoit T (2010) The age and history of the French Mediterranean steppe revisited by soil wood charcoal analysis. The Holocene 20: 25-34.

Huault MF (1986) Etude palynologique d'un sondage dans le marais de La Harelle, Heurteauville (SeineMaritime). Revue Archéologique de L'ouest 1: 23-27.

Jacquiot C (1955) Atlas d'anatomie des bois et des conifères. Paris: Centre Technique du Bois et Fonds Forestier National.

Jacquiot C, Trenard Y and Dirol D (1973) Atlas d'anatomie des bois d'Angiospermes. Paris: Centre Technique du Bois et Fonds Forestier National.

Jalut G, Dedoubat JJ, Fontugne M et al. (2009) Holocene cir-cumMediterranean vegetation changes: Climate forcing and human impact. Quaternary International 200: 4-18.

Janssen CR and Janssen-Kettlitz EL (1972) A post-Atlantic pollen sequence from the tourbière du Tanet (Vosges, France). Pollen et Spores 14: 67-77.

Kahmen S and Poschlod P (2004) Plant functional trait responses to grassland succession over 25 years. Journal of Vegetation Science 15: 21-32.

Kahmen S, Poschlod P and Schreiber K-F (2002) Conservation management of calcareous grasslands: Changes in plant spe-cies composition and response of functional traits during 25 years. Biological Conservation 104: 319-328.

Kalis AJ, Merkt J and Wunderlich J (2003) Environmental changes during the Holocene climatic optimum in central Europe Human impact and natural causes. Quaternary Sci-ence Reviews 22: 33-79.

Karlík P and Poschlod P (2009) History or abiotic filter: Which is more important in determining the species composition of calcareous grasslands? Preslia 81: 321-340.

Kuneš P, Svobodova-Svitask H, Kolar J et al. (2015) The origin of grasslands in the temperate forest zone of east-central Europe: Long-term legacy of climate and human impact. Quaternary Science Reviews 116: 15-27.

Lecompte M and Cohen M (1985) Le climat du Causse Méjan (8301247m): montagnard et méditerranéen ? Méditerranée 56: 3135.
Marlon JR, Bartlein PJ, Carcaillet C et al. (2008) Climate and human influences on global biomass burning over the past two millennia. Nature Geoscience 1: 697-702.

Molliex S, Siame LL, Bourlès DL et al. (2013) Quaternary evolution of a large alluvial fan in a periglacial setting (Crau Plain, SE France) constrained by terrestrial cosmogenic nuclide (Be-10). Geomorphology 195: 45-52.

Nelle O, Robin V and Talon B (2013) Pedoanthracology: Analysing soil charcoal to study Holocene palaeoenvironments. Quaternary International 289: 1-4.

Pärtel M, Helm A, Reitalu T et al. (2007) Grassland diversity related to the Late Iron Age human population density. Jour-nal of Ecology 95: 574-582.

Pokorny P, Chytry M, Jurickova L et al. (2015) Mid-Holocene bottleneck for central European dry grasslands: Did steppe survive the forest optimum in northern Bohemia, Czech Republic? The Holocene 25: 716-726.

Pons A and Quezel P (1998) A propos de la mise en place du climat méditerranéen. Comptes Rendus de L'académie des Sci-ences 327: 755-760.

Poschlod P and Baumann A (2010) The historical dynamics of calcareous grasslands in the central and southern Franconian Jurassic mountains: A comparative pedoanthracological and pollen analytical study. The Holocene 20: 13-23.

Poschlod P and WallisDeVries MF (2002) The historical and socioeconomic perspective of calcareous grasslands: Lessons from the distant and recent past. Biological Conservation 104: 361-376.

Poschlod P, Baumann A and Karlik P (2009) Origin and development of grasslands in central Europe. In: Veen P, Jefferson R, de Smidt $\mathrm{J}$ et al. (eds) Grasslands in Europe of High Nature Value. Uitgeverij: KNNV Publishing, pp. 15-25.

Power MJ, Marlon J, Ortiz N et al. (2008) Changes in fire regimes since the Last Glacial Maximum: An assessment based on a global synthesis and analysis of charcoal data. Climate Dynamics 30: 887-907.

Rameau JC, Mansion D and Dumé G (1999) Flore forestière française tome 2: Montagnes. Paris: IDF.

Rameau JC, Mansion D and Dumé G (2005) Flore forestière française tome 1: Plaines et collines. Paris: IDF.

Rameau JC, Mansion D, Dumé G et al. (2008) Flore forestière française tome 3: Montagnes. Paris: CNPPF - IDF.

Robin V and Nelle O (2014) Contribution to the reconstruction of central European fire history, based on the soil charcoal analysis of study sites in northern and central Germany. Vegetation History and Archaeobotany 23: 51-65.

Robin V, Bork H-R, Nadeau M-J et al. (2014) Fire and forest history of central European low mountain forest sites based on soil charcoal analysis: The case of the eastern Harz. The Holocene 24: 35-47.

Robin V, Nadeau M-J, Grootes PM et al. (2016) Palaeobotanical and climate data support the plausibility of temperate trees spread into central Europe during the Late Glacial. New Phytologist 212: 19-21.

Robin V, Rickert B-H, Nadeau M-J et al. (2012) Assessing Holocene vegetation and fire history by a multiproxy approach: The case of Stodthagen Forest (Northern Germany). The Holocene 22: 337-346.

Robin V, Talon B and Nelle O (2013) Pedoanthracological contribution to forest naturalness assessment. Quaternary International 289: 5-15.

Römermann C, Dutoit T, Poschlod P et al. (2005) Influence of former cultivation on the unique Mediterranean steppe of France and consequences for conservation management. Biological Conservation 121: 21-33.

Schrautzer J, Jansen D, Breuer M et al. (2009) Succession and management of calcareous dry grasslands in the Northern Franconian Jura, Germany. Tuexenia 29: 339-351. 
Schwartz D, Goepp S, Ertlen D et al. (2014) Les défrichements anciens dans les massifs du Hohneck et du Rossberg. Une histoire revisitée des Hautes-Chaumes vosgiennes. In: Rothiot J$\mathrm{P}$ and Husson J-P (eds) La Bresse et ses vallées. Epinal: Editions de la Fédération des Sociétés Savantes des Vosges, Racines Bressanes, Maison des Loisirs et de la Culture, pp. 61-76.

Schwartz D, Thinon M, Goepp S et al. (2005) Premières datations directes de défrichements protohistoriques sur les chaumes secondaires des Vosges (Rossberg, Haut-Rhin). Approche pédoanthracologique. Comptes Rendus de Geoscience 337: 1250-1256.

Schweingruber FH (1990) Anatomy of European Woods. Bern; Stuttgart: Verlag Paul Haupt.

Svenning JC (2002) A review of natural vegetation openness in north-western Europe. Biological Conservation 104: 133- 148.

Talon B (2010) Reconstruction of Holocene high-altitude vegetation cover in the French Southern Alps: Evidence from soil charcoal. The Holocene 20: 34-44.

Théry-Parisot I (2001) Economie des combustibles au Paléolithique. Paris: CNRS.

Thiebault S (1997) Early-Holocene vegetation and the human impact in central Provence (Var, France): Charcoal analysis of the Baume de Fontbrégoua. The Holocene 7: 343-349.

Thinon M (1978) La pédoanthracologie: une nouvelle méthode d'analyse phytochronologique depuis le Néolithique. Comptes Rendus de L'académie des Sciences 287: 1203-1206.

Thomas KD (1989) Vegetation of the British chalklands in the Flandrian period: A response to Bush. Journal of Archaeological Science 16: 549-553.

Touflan P, Talon B and Walsh K (2010) Soil charcoal analysis: A reliable tool for spatially precise studies of past forest dynamics: A case study in the French Southern Alps. The Holocene 20: 4552.

Triat-Laval H (1982) Pollen analyse de sédiments quaternaires récents du pourtour de l'Étang de Berre. Ecologia Mediterranea 8 : $97-115$.
Van Campo M and Aymonin G (1962) Le problème de l'histoire de la flore et de la végétation dans les Cévennes méridionales, vu sous l'angle de l'analyse pollinique. Flora 152: 679-688.

Vannière B, Colombaroli D, Chapron E et al. (2008) Climate versus human-driven fire regimes in Mediterranean landscapes: The Holocene record of Lago dell'Accesa (Tuscany, Italy). Quaternary Science Reviews 27: 1181-1196.

Vannière B, Power MJ, Roberts N et al. (2011) Circum-Mediterranean fire activity and climate changes during the midHolocene environmental transition (8500-2500 cal. BP). The Holocene 21: 53-73.

Vassilev K, Pedashenko H, Nikolov SC et al. (2011) Effect of land abandonment on the vegetation of upland semi-natural grasslands in the Western Balkan Mts., Bulgaria. Plant Biosystems 145: 654-665.

Vera FWM (1999) Grazing Ecology and Forest History. Oxford: CABI Publishing.

Vernet J-L (2006) History of the Pinus sylvestris and Pinus nigra ssp. salzmanni forest in the Sub-Mediterranean mountains (Grands Causses, Saint-Guilhem-le-Désert, southern Massif Central, France) based on charcoal from limestone and dolomitic deposits. Vegetation History and Archaeobotany 16: $23-$ 42.

WallisDeVries MF, Poschlod P and Willems JH (2002) Chal-lenges for the conservation of calcareous grasslands in north-western Europe: Integrating the requirements of flora and fauna. Biological Conservation 104: 265-273.

Willis KJ, Rudner E and Sümegi P (2001) Reply to Carcaillet and Vernet. Quaternary Research 55: 388-389.

Wilmans O (1997) On the history of Central European dry grassland communities since the Late-Glacial: Methods, facts, hypotheses. Phytocoenologia 27: 213-233. 